\title{
ISO 14001 and 26001, Agents of Change in the SME
}

\author{
Luis Enrique Valdez-Juárez ${ }^{1}$, Dolores Gallardo-Vázquez ${ }^{2}$, Elva Alicia Ramos-Escobar ${ }^{1}$ \& Roberto Limón-Ulloa ${ }^{1}$ \\ ${ }^{1}$ Faculty of Business Administration, Guaymas, Sonora, México \\ ${ }^{2}$ Faculty of Business Management and Economics, Exremadura University, Badajoz, Spain \\ Correspondence: Luis Enrique Valdez Juárez, Faculty of Business Administration, Guaymas, Sonora, México. \\ E-mail: levaldez@itson.edu.mx
}

Received: November 26, 2018 Accepted: December 20, 2018 Online Published: January 24, 2019

doi:10.5539/jms.v9n1p32 URL: https://doi.org/10.5539/jms.v9n1p32

\begin{abstract}
At present, business strategies in SMEs (Small and medium enterprises) are crucial for consolidation in highly competitive markets, in achieving a better image and in business profitability. One of the strategies that are currently being used and that have a high level of success are the practices focused on sustainability and social responsibility, through standardized standards such as: ISO 14001 and ISO 26001. The literature related to sustainable business is based mainly on the theory of resources and capabilities, and in theory based on Stakeholders. These currents state that companies should focus on profitable strategies to ensure significant and long-term results, in order to achieve organizational and financial results for stakeholders. In this work, the sample consists of 215 companies from the commerce, services and industry sectors, located in the southern region of the State of Sonora in Mexico.The objective of the work is to analyze the influence of ISO 14001 and 26001 standards on the image and profitability of SMEs. The statistical analysis of the data has been carried out through the linear regression technique by OLS (Ordinary Least Squares). The findings prove that the ISO 14001 standard is the one that most influences the improvement of the business image and the level of profitability of the SME. In addition, we discovered that ISO 26001 has a partial influence on the image and profitability of the SME.
\end{abstract}

Keywords: SME, ISO, social responsibility, image, profitability

\section{Introduction}

Since the appearance of the industrial revolution and with the changes in economic systems, companies have been in constant movement towards learning, standardization of their processes and the ongoing struggle for competitiveness (Drucker, 2012; Nelson, 2009). To this type of organizations that live in environments with technological advances and economic obstacles, they are called as visionary, strategic and innovative (Barney, Ketchen, \& Wright, 2011). One of the effective strategic actions that in recent years has been generating value within and outside organizations, has been the implementation of certification standards related to quality management, environmental management and social responsibility practices (Bernal-Conesa, de Nieves Nieto, \& Briones-Peñalver, 2017; Rego, Cunha, \& Polónia, 2017). These regulations are controlled by the international organization for standardization (ISO-International Organization for Standardization), with the purpose of improving the internal processes of organizations (Jagd, 2014; Moratis \& Cochius, 2017). Due to strong international regulations on the subject of process improvement, the quality of products and services, and the control of natural resources, companies are becoming more aware and rational (Finkbeiner et al., 2010; Rajeev, Pati, Padhi, \& Govindan, 2017). Theories such as resources and capabilities (RBV-Resource Based View) have considered these business practices as a trigger for growth, improvement of corporate image, increased innovation and significant financial returns for their stakeholders (Barney, 2012; Sharma \& Vredenburg, 1998). However, this philosophy focuses its efforts on the social and economic aspect, often bordering on the theme of sustainability (Jayanti \& Rajeev, 2014). From another perspective, some scholars have exposed that sustainability and social practices have penetrated with force in their organizational results (Freeman, Harrison, Wicks, Parmar, \& de Colle, 2010). Stakeholders theory (interest groups) has been one of the main axioms taken as reference by specialists in the subject to support that sustainable businesses with social and environmental actions achieve significant organizational and financial benefits (Freeman, 2010). These benefits usually focus on investors, internal customers, external customers, suppliers and the inhabitants of the communities. This is achieved through collaborative work between the different actors involved in the social economy (Abagail, 
Parhankangas, Coupet, Welch, \& Barnum, 2016; Abagail, Siegel, \& Wright, 2006). Undoubtedly, these two theories conceive that the ISO 14001 standard focused on the sustainability of business can contribute more to the reputation and business image (Bansal \& Hunter, 2003). In the same direction, the ISO 26001 standard, focused on the management of social responsibility, has recently been a business practice of great value for business (Moratis \& Cochius, 2017). Among the most significant benefits of these regulations, is that they help to standardize processes, improve the quality of products (sustainable), improve collaborative work, strengthen productive work, reduce costs, increase image and strengthen the organizational reputation ( $\mathrm{Su}$, Dhanorkar, \& Linderman, 2015). However, in the case of the SME (small and medium enterprises), the implementation of these standards has been a complicated and pending issue. The main barriers faced by these organizations to incorporate these practices, mainly focus on the lack of financial budget (high implementation and monitoring costs), the short-term vision of managers and the lack of commitment of investors and employees (Aagaard, 2016; Ho, Nguyen, Adhikari, Miles, \& Bonney, 2017; Moratis \& Cochius, 2017). Derived from the above, we have defined that the main objective of this work is to empirically analyze the effect of the environmental standard ISO 14001 and the social responsibility standard ISO 26001, on the image and profitability of SMEs in the southern region of the State of Sonora in Mexico. The research questions we present and try to answer are: 1) Does the SME that focuses its resources and capacities on the implementation of the ISO 14001 standard obtain higher results of image and corporate performance? 2) The SME that focuses its resources and capacities on the implementation of the ISO 26001 standard obtains higher image results and business performance? This work contributes to the literature of the resources and capacities and to the theory the groups of interest from two perspectives. First, analyzing the ability of companies (SMEs) in the application of human and financial resources in terms of standardization and standardization of their processes, with the firm purpose of strengthening their image and increase their performance in competitive markets. In the literature there is a considerable number of empirical studies that analyze the business, environmental and financial benefits that are achieved through the standardization of their processes (Dobers, 2009; Hahn, 2012; Heras \& Arana, 2010). However, these works mostly focus on the study of large companies with international scope (Christmann, 2004; Hahn \& Kühnen, 2013; Abagail et al., 2006). Second, from the perspective of the Stakeholder theory, we analyze the benefits that occur within the SME, derived from the application of environmental standards and CSR (Corporate Social Responsibility) practices in global markets (Carroll \& Shabana, 2010; Spence, 2016). In this same direction, we have detected that a large number of researchers have studied these variables in multinational companies, leaving aside the impacts of these variables within the SME. The research has been structured through: 1) literature review, and development of hypotheses for analysis; 2) the second section describes the methodology, the sample and the justification of the variables under study; 3 ) the third section examines the results obtained and 4) finally the main conclusions and discussions are presented.

\section{Review of Literature and Development of Hypothesis}

\subsection{ISO 14001 and 26001 Standards, in the Business Image}

Some theoretical currents, such as the Stakeholders and the RBV, have concluded that there are companies of different sizes that have achieved success through the implementation of quality and environmental standards (Barney, Wright, \& Ketchen, 2001; Ferrón-Vílchez, 2016). Taking sustainability as a reference, businesses are adopting economic models that will lead them to improve their profitability (Neil, Anna, \& Katsikeas, 2004). For this, companies have a greater occupation for the environmental care issue, for the satisfaction of internal and external customers (Camilleri, 2017; Khan \& Chang, 2018). For example, recently some scholars have concluded that an effective way to generate wealth for investors, is improving the working conditions of employees, improve quality processes and care for the environment, this through the so-called circular economy (McCormick \& Kautto, 2013; Witjes \& Lozano, 2016). The issue of sustainability and social responsibility in the last decade has been a business strategy aimed at improving innovation, reputation, image and contributes to the business leadership of the business (Cantele \& Zardini, 2018; Abagail et al., 2016; Salim et al., 2018). A large number of studies in Europe and North America have concluded that SMEs have a serious problem when implementing environmental management systems, this has caused disinterest and a null value added (Heras \& Arana, 2010; Hillary, 2004; Valdez-Juárez et al., 2018). On the other hand, several studies have confirmed that the implementation of standards focused on sustainable and environmental actions, help in the design and innovation of products, control their production processes, improve the strengthening of the image, improve the perception of the community (customers) and the benefits for investors are maximized (Ferrón-Vílchez, 2016; Granly \& Welo, 2014).In the subject of social responsibility, the regulation for companies through the standard 26001 is currently a business practice that is mostly applied as a marketing strategy (von Weltzien Hoivik, 2011). This is because it is adopted for convenience and not for conviction (ethics and moral) (Jagd, 2014). Some 
research in the field of SMEs from countries with developed and emerging economies have exposed that these practices generate a greater projection of the commercial image of companies, increase the satisfaction of their stakeholders and increase the business reputation (Jayanti \& Rajeev, 2014; Poveda \& Young, 2015). From the theoretical and empirical analysis we have developed the following hypotheses:

H1a. A greater focus (implementation) in the ISO 14001 standard, the SME becomes an innovative company.

H1b. A greater focus (implementation) in the ISO 14001 standard, the SME is consolidated as a leader in its sector.

H1c. A greater focus (implementation) in the ISO 14001 standard, the SME is consolidated as a safe company.

H1d. A greater focus (implementation) in the ISO 14001 standard increases the business image in the SME.

H2a. A greater focus (implementation) in the ISO 26001 standard, the SME becomes an innovative company.

$\mathrm{H} 2 \mathrm{~b}$. A greater focus (implementation) in the ISO 26001 standard, the SME is consolidated as a leader in its sector.

H2c. A greater focus (implementation) in the ISO 26001 standard, the SME is consolidated as a secure company.

H2d. A greater focus (implementation) in the ISO 26001 standard increases the business image in the SME.

\subsection{The Norms ISO 14001 and 26001, in the Business Profitability}

The theory of resources and capabilities has exposed during the last two decades that organizations that focus their efforts on strategies based on business sustainability, manage to develop products and services with greater value, increase innovation, improve profitability and strengthen their administrative processes and productive (Barney et al., 2011; Freeman et al., 2010). Numerous studies developed in large organizations have explained that environmental management and CSR are correlated and that, in addition, they generate significant financial returns (Aagaard, 2016; Porter \& Kramer, 2011). In the field of SMEs, some researchers have reported mostly that environmental management standards and CSR actions are in a development phase (Lueg \& Radlach, 2016; Moore \& Manring, 2009). But in this last decade, there is a greater interest in putting them into practice by small businesses, this because of the benefits that are achieved (Jamali \& Karam, 2018). For example, scholars in the subject have exposed that the SMEs that carry out these practices and/or business strategies manage to improve their processes, manage to efficiently manage logistics, and standardize products and services. These actions lead them to more competitive markets and to the total satisfaction of their customers (Cantele \& Zardini, 2018; Graafland, 2018). In addition, with strategies aimed at environmental sustainability and commitment to stakeholders, companies achieve the improvement of the business image, innovation is increased, they manage to penetrate new markets with greater force, they manage to increase the level of customers, they increase their sales, competitiveness increases and consequently the financial and economic profitability increases (Ageron \& Spalanzani, 2012; Dey et al., 2018; Gianni, Gotzamani, \& Tsiotras, 2017; Torugsa, O’Donohue, \& Hecker, 2012). After reviewing the theoretical and empirical context, the following hypotheses have been developed:

H3a. A greater focus (implementation) in the ISO 14001 standard increases the market share in the SME.

H3b. A greater focus (implementation) in the ISO 14001 standard increases the level of satisfaction of the SME's customers.

H3c. A greater focus (implementation) in the ISO 14001 standard increases the profits of the SME.

H3d. A greater focus (implementation) in the ISO 14001 standard increases the profitability of the SME.

H4a. A greater focus (implementation) in the ISO 26001 standard increases the market share in the SME.

H4b. A greater focus (implementation) in the ISO 26001 standard increases the level of satisfaction of SME customers.

H4c. A greater focus (implementation) in the ISO 26001 standard increases the profits of the SME.

H4d. A greater focus (implementation) in the ISO 26001 standard increases the profitability of the SME. 


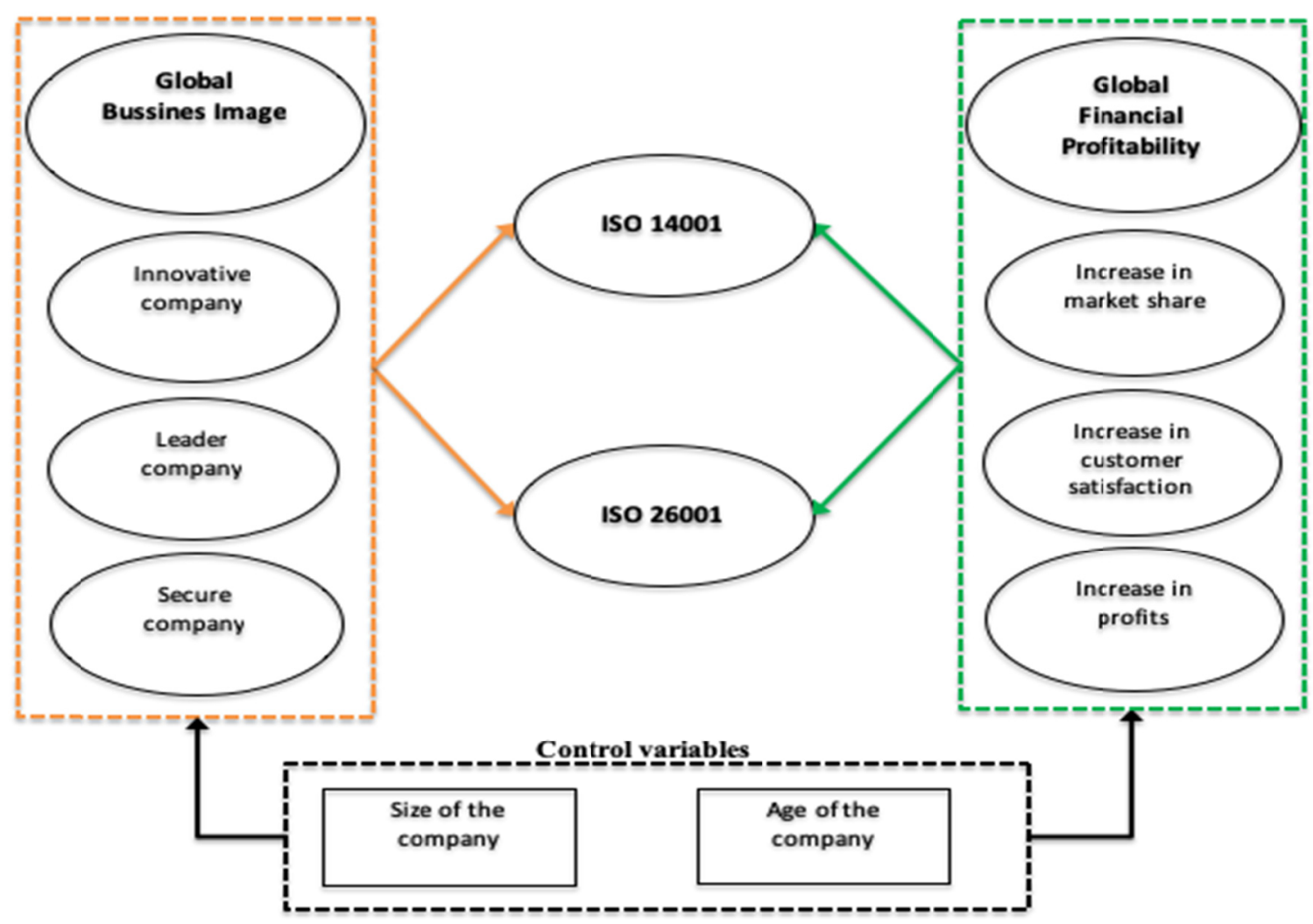

Figure 1. Theoretical model of research.

Note. In this Figure, we show the theoretical model of the research and the relationships (hypotheses) structured on the ISO 14001, ISO 26001 standards, with the variables of the business image and financial profitability. In addition, the relationship between the variables of control size of the company and age of the company on the image and profitability is displayed.

\section{Method}

The structure and determination of the sample has been developed based on the principles of stratified sampling for finite populations. The population of companies is segmented according to the business activity. The companies in the trade, services and industrial sectors are the participants in the research. The total number of companies established in the southern region of the State of Sonora in Mexico (Cajeme and Guaymas). Each one of the built sectors has been obtained from the information provided by the economic census of the National Institute of Statistics and Geography, INEGI (2014). Companies with 10 to 100 workers are included in the sample. The sample size was determined to ensure that the maximum margin of error for the estimation of a proportion was less than 0.03 points with a confidence level of $95 \%$. In this region there is a total of 90,642 companies. Of which $16.8 \%$ are in the Cajeme region and $5.4 \%$ in the Guaymas region. To determine the sample, the formula for finite populations no larger than 500,000 subjects has been used (see Table 1) (Israel, 1992; Naing, Winn, \& Rusli, 2006). The results indicate that the total sample is 377 companies. However, in our simple random sampling, we have compiled a total of 354 surveys, which is $94 \%$ of the total sample suggested (see Table 2). The technique for collecting the information was through a personal interview (questionnaire) addressed to the manager of the companies (see Appendix A). The fieldwork for data collection was carried out during the months of May to September 2016. In a first phase, a pilot test was carried out with $5 \%$ of the total sample, in order to improve the structure and validation of the instrument (Sarantakos, 2001). Companies that refused to participate in the project were replaced by a similar company (chosen randomly) of the same business and geographical area. The bias of response was not analyzed (Nwachukv, Vitell, Gilbert, \& Barnes, 1997) interviews ( $80 \%$ of the sample) were compared with those that responded by replacement ( $20 \%$ of the sample). No significant differences between the two groups emerged from the variables considered, using $t$ tests and chi-square tests. For purposes of this investigation, the sample that was considered was to include only 
companies that had experienced the implementation of ISO 140001 and 260001 standards. Finally, a sample of 215 companies that comply with these characteristics was obtained (see Table 3).

Table 1. Determination of the sample

\begin{tabular}{lll}
\hline DATA & & CONVERSION \\
\hline $\mathrm{N}$ & 20,123 & \\
$\mathrm{p}$ & $50 \%$ & 0.50 \\
$\mathrm{q}$ & $50 \%$ & 0.50 \\
$\sigma$ & $95 \%$ & 1.96 \\
$\mathrm{e}$ & $5 \%$ & 0.05 \\
$\mathrm{n}$ & 377 & \\
\hline
\end{tabular}

Note. $\mathrm{N}=$ Universe, $\mathrm{p}=$ probability in favor, $\mathrm{q}=$ probability against, $\sigma=$ confidence coefficient, es=estimation error, $\mathrm{n}=$ sample.

Table 2. Conformation of the population

\begin{tabular}{lllll}
\hline Sector & No. companies & SB & MB & \% total \\
\hline Trade & 176 & 81 & 95 & 49.7 \\
Services & 101 & 39 & 62 & 28.5 \\
Industrial & 77 & 14 & 63 & 21.8 \\
Total & 354 & 134 & 220 & 100.0 \\
\hline
\end{tabular}

Table 3. Conformation of the sample

\begin{tabular}{lllll}
\hline Sector & No. companies & SB & MB & \% total \\
\hline Trade & 88 & 35 & 53 & 40.9 \\
Services & 55 & 24 & 31 & 25.6 \\
Industrial & 72 & 9 & 63 & 33.5 \\
Total & 215 & 68 & 147 & 100.0 \\
\hline
\end{tabular}

Note. Table 3 presents the total of the subsample selected by business sector (trade, service \& industry) that participates in the research. SB (Small Business, from 10 to 50 workers), MB (Medium Business, from 51 to 100 workers).

\subsection{Measurement of the Variables}

To choose the correct statistical technique, we have analyzed the behavior of the data of the dependent variables (metrics) through the Kolmogorov-Smirnov test (see Table $4 \& 5$ ). In our research we have chosen the linear regression test, which has as a condition that the data are normal, for this purpose we have transformed our dependent variables into natural logarithms in order to comply with this requirement. In this test, two hypotheses have been developed: 1) Null hypothesis (Ho), the data of the dependent variables follow a normal distribution, and 2) Alternative hypothesis (Ha), the data of the dependent variables do not follow a normal distribution. Additionally, we have developed the test of equality of variance of the data of the independent variables (ISO $14001 \&$ ISO 26001), with respect to the dependent variables (Business Image and Financial Profitability). This has been made clear through the analysis of the ANOVA with Levene Statistics (see Table $6 \&$ 7). Therefore, two hypotheses have been developed. 1. Null Hypothesis (Ho): There are no significant differences of the independent variables with respect to the dependent variables, and 2. Alternative hypothesis (Ha): There are significant differences of the independent variables with respect to the dependent variables. The regression analysis deals with the study of the dependence of a variable to explain with respect to one or more explanatory variables (Gefen, Straub, \& Boudreau, 2000; Kleinbaum, Kupper, Nizam, \& Rosenberg, 2013). The objectives of this multivariate technique among the most important are: 1. Determine the structure or form of the relationship, that is, the mathematical equation that relates the independent variables with the dependent ones, 2 . Verify hypotheses deduced from the analyzed theory, and 3 Predict the values of the dependent variable and perform simulations. In our study, we decided to use this statistical technique, due to the following factors: 1. It is better adapted to the objective of the research (explanatory type); 2. Due the nature and characteristics of the variables; and 3. Due to the sample size that is analyzed. 
Table 4. Normality test

\begin{tabular}{llll}
\hline Variable (Global Image) & Statistics & $\mathrm{gl}$ & P Value \\
\hline An innovative company & 0.093 & 215 & 0.043 \\
A leading company & 0.098 & 215 & 0.034 \\
A safe company & 0.087 & 215 & 0.068 \\
\hline
\end{tabular}

Table 5. Normality test

\begin{tabular}{llll}
\hline Variable (Global Financial Profitability) & Statistics & $\mathrm{gl}$ & P Value \\
\hline Increase in market share & 0.065 & 215 & 0.189 \\
Increase in customer satisfaction & 0.074 & 215 & 0.182 \\
Increase in profits & 0.085 & 215 & 0.076 \\
\hline
\end{tabular}

Table 4 and 5 report that the data of the dependent contributors follow a normal distribution, after having been transformed into natural logarithm. According to Wilcox (1997) and Cohen, West, \& Aiken (2014), when the value of $\mathrm{P}$ is greater than $0.05(\mathrm{p}>0.05)$ the data have a normal behavior. According to these results $(\mathrm{Ha})$ has been rejected.

Table 6. Homogeneity test

\begin{tabular}{lllll}
\hline Dependent variable (ISO14001) & Levene Statistics & g11 & g12 & P Value \\
\hline An innovative company & 2.234 & 1 & 215 & 0.102 \\
A leading company & 1.515 & 1 & 215 & 0.219 \\
A safe company & 1.194 & 1 & 215 & 0.221 \\
Increase in market share & 1.377 & 1 & 215 & 0.242 \\
Increase in customer satisfaction & 0.723 & 1 & 215 & 0.478 \\
Increase in profits & 1.582 & 1 & 215 & 0.208 \\
\hline
\end{tabular}

Table 7. Homogeneity test

\begin{tabular}{lllll}
\hline Dependent variable (ISO26001) & Levene Statistics & g11 & gl2 & P Value \\
\hline An innovative company & 1.779 & 1 & 215 & 0.245 \\
A leading company & 1.624 & 1 & 215 & 0.289 \\
A safe company & 0.897 & 1 & 215 & 0.478 \\
Increase in market share & 2.459 & 1 & 215 & 0.079 \\
Increase in customer satisfaction & 4.494 & 1 & 215 & 0.038 \\
Increase in profits & 0.572 & 1 & 215 & 0.691 \\
\hline
\end{tabular}

Table 6 and 7 show that the data of the independent variables with respect to the dependent variables have equality of variances, after having made the Levene statistic. According to Wilcox \& Spring (2007), when the value of $\mathrm{P}$ is greater than 0.05 ( $\mathrm{p}>0.05)$, there is equality of variances. According to these results $(\mathrm{Ha})$ it has been rejected.

\subsubsection{Exogenous Variables (Categorical Variable)}

ISO 14001, 26001. The literature has exposed that the norms and/or environmental regulations and corporate social responsibility, are generators of innovation, growth, image, reputation and financial profitability in organizations (Aagaard, 2016; Masurel, 2007). From the theoretical and empirical review, a series of structured questions were developed in a questionnaire addressed to SME managers. Respondents were asked to indicate if in their company they had introduced environmental management (ISO 14001) and ISO (26001) social responsibility standards in their internal processes. To the values given for the positive answers (yes), the 1 was assigned and for the negative answers (no) the value of 0 was assigned.

\subsubsection{Endogenous Variables (Discrete Quantitative Variable)}

The Business Image. In this study, the managers answered the questions of the questionnaire to assess the degree of importance of the results obtained in the corporate image in terms of environmental regulations and social responsibility practices during the last two years. This variable was measured with 3 items that comprise it: 1 . Innovative company, 2. Leader company and 3. Secure company. In addition, the business image variable was also measured through the average of the three items that build it. For this, a Likert scale of 5 points was used 
with $1=$ Not important and $5=$ Very important. For the development of this construct reference studies have been taken of Sarbutts (2003), Jenkins (2004) and Lee (2008), observe Table 8.

Table 8 . Reliability and validity

\begin{tabular}{lll}
\hline Variable (Global Image) In the last 2 years & Factor Load & Validation of the variable \\
\hline An innovative company & 0.804 & $\alpha$ Cronbach $=0.670$, Factorial: $1:$ KMO: 0.678 \\
A leading company & 0.815 & Explained variance: $60.09 \%$, Sig. Bartlett: 0.000 \\
A safe company & 0.677 & \\
\hline
\end{tabular}

Note. Table 8 shows the validation of the global image construct. In addition, the validity and reliability of the variable is shown through the factorial loads, the Cronbach's $\alpha$, the KMO (Kaiser-Meyer-Olkin) and the variance explained.

Financial profitability. To measure this variable, we have considered the relationship and influence that financial results receive from ISO standards, social responsibility practices and corporate image (Carroll \& Shabana, 2010; Wood, 2010). In this study, the managers answered the questions of the questionnaire to classify the degree of importance of the profitability of the SME obtained in the last two years. The variable was measured with 3 items: 1. Increase in market share, 2. Increase in customer satisfaction, and 3. Increase in profits. In addition, this variable was also measured globally by building an average of the three components that make up the business profitability of the SME. For this, a Likert scale of 5 points was used with $1=$ Poor performance and $5=$ High performance. For the development of this construct have been developed taking as reference the studies developed by Orlitzky, Schmidt, \& Rynes (2003) and by Melnyk \& Tobias (2014), see Table 9.

Table 9. Reliability and validity

\begin{tabular}{lll}
\hline Variable (Global Financial Profitability) In the last 2 years & Factor Load & Validation of the variable \\
\hline Increase in market share & 0.780 & $\alpha$ Cronbach $=0.776$, Factorial: 1: KMO: 0.787 \\
Increase in customer satisfaction & 0.833 & Explained variance: $57.20 \%$, Sig. Bartlett: 0.000 \\
Increase in profits & $0 . .754$ & \\
\hline
\end{tabular}

Note. Table 9 shows the validation of the global financial profitability construct. In addition, the validity and reliability of the variable is shown through the factorial loads, the Cronbach's $\alpha$, the KMO (Kaiser-Meyer-Olkin) and the variance explained.

\subsubsection{Control Variables}

Frequently the structural size and age of the company are seen as a determining factor in the generation of economic and financial performance for organizations (Penrose, 2009). The size of the company, this variable was measured with the natural logarithm of the total of the employees of the year 2016. The age of the company, in the literature and in empirical studies this variable is used in the research models to analyze the financial influence and economic growth that is generated in organizations during a given period of time (Benitez-Amado $\&$ Walczuch, 2012). The age of the company determines the degree of consolidation and maturity within a market, results that are explained through the evolutionary theory (Nelson, 2009). This variable is measured based on the start of the operation and up to the current activities of the companies, see Table 10.

Table 10. Size and age of the company

\begin{tabular}{lllll}
\hline Característic & Mínimum & Máxim & Media & Deviation Typical \\
\hline Company's age & 1 & 36 & 14.00 & 15,456 \\
Size of the company (number of employees) & 10 & 96 & 18.00 & 27,332 \\
\hline
\end{tabular}

\subsection{Reliability and Validity}

For the evaluation of the reliability and validity of the endogenous variables of the instrument, an Exploratory Factor Analysis (EFA) was performed through the maximum likelihood method, using the SPSS software version 21. The reliability of the measurement scales was evaluated using the Cronbach's alpha, the percentage of variance explained, the KMO (The Kaiser-Meyer-Olkin test) and the factorial loads. Cronbach's alpha is considered satisfactory above 0.60 and/or close to 0.70 (Hair, Black, Babin, Anderson, \& Tatham, 2006). Our results are within the values of 0.670 and 0.776 , demonstrating an acceptable reliability between the constructs. The KMO is measured in a range of 0 to 1 . To consider an acceptable measure and a satisfactory interrelation 
between the items is recommended to obtain a value close to and/or equal to 0.700 (Hair et al., 2006). Our results are in a range of 0.678 and 0.787 , indicating good reliability. With respect to the variance explained, our values are $57 \%$ and $60 \%$. For this indicator it is recommended that the factorial solution explain, at least, $50 \%$ of the total variability of the test response (Merenda, 1997; Nasser, Benson, \& Wisenbaker, 2002). With regard to factor loads, the results obtained are 0.677 and 0.833 , this indicator is convenient to provide results above 0.600 as suggested by (Bagozzi \& Yi, 1988; Hair et al., 2006). Other authors recommend that these values be close to or above 0.707 as proposed by Carmines \& Zeller (1991) and Christmann \& Steinwart (2008). The validity of the scales has been carried out through the theoretical and empirical review (content validity). With the previous analyzes it is concluded that the theoretical model has an adequate consistency, validity and reliability among all the constructs.

\section{Results}

To validate the hypotheses presented in the research and verify the effect that environmental and social responsibility standards have on the corporate image and profitability, the linear regression model by OLS was used. To test the hypothesis, four linear regression models were developed with the following equations. The first equation represented in model 1 , outlines the influence that the business image ( $\beta$ o) receives from ISO14001 ( $\beta 1)$, the size of the company $(\beta 2)$ and the age of the company $(\beta 3)+£$ (error). In model 2 , the designed equation symbolizes the effect that the business image ( $\beta \mathrm{o})$ receives from ISO26001 ( $\beta 1)$, the size of the company $(\beta 2)$ and the age of the company $(\beta 3)+£$ (error). In model 3 , the equation is observed indicating the influence that business profitability ( $\beta$ o) receives from ISO14001 ( $\beta 1)$, the size of the company ( $\beta 2)$ and the age of the company $(\beta 3)+£$ (error). In the last structured equation represented in model 4 , we observe the influence that business profitability ( $\beta$ o) receives from ISO26001 ( $\beta 1)$, the size of the company ( $\beta 2)$ and the age of the company $(\beta 3)+£$ (error).

1) Model 1. Business image $e_{i} \beta_{o}+\beta_{1 x}$ ISO14001 ${ }_{i+} \beta_{2 x}$ size of the company ${ }_{+} \beta_{3 x}$ age of the company ${ }_{+} £$

2) Model 2. Business image $e_{i}=\beta_{o}+\beta_{1 x}$ ISO26001 ${ }_{i}+\beta_{2 x}$ size of the company $\beta_{3 x}$ age of the company $+£$

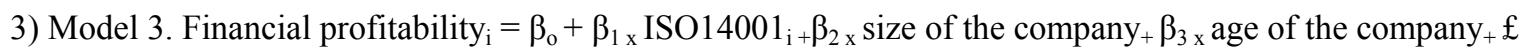

4) Model 4. Financial profitability ${ }_{i}=\beta_{o}+\beta_{1 x} I S O 26001_{i+} \beta_{2 x}$ size of the company $\beta_{+} \beta_{3 x}$ age of the company $y_{+} £$

Table 11. Relationship between the variables (ISO 14001, $26001 \&$ the business image)

\begin{tabular}{lllll}
\hline Exogenous Variables & \multicolumn{5}{c}{ Endogenous variables } \\
\hline Environmental and CSR standards & $\begin{array}{l}\text { Innovative Company } \\
\text { Coef. (value t) }\end{array}$ & $\begin{array}{l}\text { Leading Company } \\
\text { Coef. (value t) }\end{array}$ & $\begin{array}{l}\text { Safe Company } \\
\text { Coef. (value t) }\end{array}$ & $\begin{array}{l}\text { Global image } \\
\text { Coef. (value t) }\end{array}$ \\
\hline ISO 14001 & $0.198^{* * *}$ & $0.213^{* * *}$ & $0.174^{* * *}$ & $0.238^{* *}$ \\
& $(3.483)$ & $(3.677)$ & $(3.059)$ & $(4.195)$ \\
ISO 26001 & 0.002 & -0.073 & $0.117^{* *}$ & -0.066 \\
& $(.008)$ & $(-1.225)$ & $(2.007)$ & $(-1.137)$ \\
Age of the company & 0.033 & $-0.012(-.218)$ & 0.017 & 0.075 \\
& $(.626)$ & & $(.321)$ & $(1.387)$ \\
Size of the company & $0.122^{* * *}$ & $0.002(0.035)$ & $-.0103^{*}$ & 0.027 \\
& $(2.154)$ & & $(-1.819)$. & $(.609)$ \\
Highest VIF & 1.29 & 1.29 & 1.29 & 1.28 \\
Value of F & $4.641^{* * *}$ & $2.745^{* * *}$ & $1.928^{* * *}$ & $5.611^{* * *}$ \\
$\mathrm{R}^{2}$ adjusted & 0.059 & 0.035 & 0.070 & 0.064 \\
\hline
\end{tabular}

Note. Table 11 shows the results of the linear regression of the (H1a, H1b, H1c, H1d) and (H2a, H2b, H2c, H2d), the value of the standardized coefficients and below them in parentheses the Student $t$ value is observed, the values of the Highest VIF, the value of $f$, and the value of $\mathrm{R}^{2}$ adjusted. In addition, the levels of significance are presented according to the values of: *, **,*** indicating the level of significance at $10 \%$ to $5 \%$ and $1 \%$ respectively.

Table 11 presents the regression results of model 1 and 2. This table represents the relationship between ISO 14001 and ISO 26001, with the corporate image. The results show empirical support for H1a, H1b, H1c, H1d, and H2c. However, for H2a, H2b and H2d we did not find empirical support. The hypotheses H1a, H1b, H1c and H1d have a strong and significant positive influence on the corporate image according to the values of $(\beta=0.198$, $\mathrm{p}<0.001),(\beta=0.213, \mathrm{p}<0.001),(\beta=0.174, \mathrm{p}<0.001)$ y $(\beta=0.238, \mathrm{p}<0.001)$. This allows us to assume that the implementation of ISO 14001 in the SME increases the corporate image. The H2c, indicates that the ISO 26001 has a positive and significant influence on the corporate image, according to the value of $(\beta=0.117, p<0.05)$. 
With this the SME is perceived as a safe company. In relation to the control variables introduced in both models, the results indicate that only the size of the company has a positive and significant influence on the variable innovative company according to the value of $(\beta=0.122, p<0.001)$. On the contrary, we find that the size of the company with a significant and negative effect exerts an influence on the variable of a secure company, according to the value of $(\beta=-0.103, p<0.01)$. In order to validate the linear regression models of the hypothesis, the $R^{2}$ adjusted with a value of (0.059), (0.035), (0.070) (0.064) and the values in F of $\left(4.641^{* * *}\right),\left(2.745^{* * *}\right)$, $\left(1.928^{* * *}\right)$ and $\left(5.611^{* * *}\right)$. In addition, the independent variables of the linear regression model show the variance inflation factor (VIF) close to the unit of (1.29), (1.29), (1.29) and (1.28), with this we rule out the presence of multicollinearity.

Table 12. Relationship between ISO 14001, 26001 and business profitability

\begin{tabular}{lllll}
\hline Exogenous Variables & \multicolumn{3}{c}{ Endogenous variables } \\
$\begin{array}{l}\text { Environmental and CSR } \\
\text { standards }\end{array}$ & $\begin{array}{l}\text { Increase in market share } \\
\text { Coef. (value t) }\end{array}$ & $\begin{array}{l}\text { Increase in customer } \\
\text { satisfaction } \\
\text { Coef. (value t) }\end{array}$ & $\begin{array}{l}\text { Increase in profitability } \\
\text { Coef. (value t) }\end{array}$ & $\begin{array}{l}\text { Globalfinancial } \\
\text { profitability } \\
\text { Coef. (value t) }\end{array}$ \\
\hline ISO 14001 & $-0.170^{* * *}$ & $0.200^{* * *}$ & $0.142^{* * *}$ & $0.182^{* *}$ \\
& $(-2.970)$ & $(3.521)$ & $(2.453)$ & $(3.352)$ \\
ISO 26001 & $0.128^{* *}$ & 0.061 & -0.028 & $0.121^{* *}$ \\
& $(2.166)$ & $(1.038)$ & $(-.477)$ & $(2.064)$ \\
Age of the company & -0.032 & -0.012 & 0.013 & -0.015 \\
& $(-0.605)$ & $(-0.218)$ & $(0.238)$ & $(-0.279)$ \\
Size of the Company & $0.126^{* * *}$ & 0.002 & 0.047 & -0.034 \\
& $(2.158)$ & $(0.035)$ & $(0.811)$ & $(-0.628)$ \\
Highest VIF & 1.29 & 1.28 & 1.29 & 1.28 \\
Value F & $3.657^{* * *}$ & $5.151^{* * *}$ & $2.594^{* * *}$ & $5.485^{* * *}$ \\
$\mathrm{R}^{2}$ adjusted & 0.047 & 0.070 & 0.037 & 0.062 \\
\hline
\end{tabular}

Note. Table 12 shows the results of the linear regression of (H3a, H3b, H3c, H3d) and (H4a, H4b, H4c, H4d), the value of the standardized coefficients and below them in parentheses the Student $t$ value is observed, the values of the Highest VIF, the value of $F$, and the value of $R^{2}$ adjusted. In addition, the levels of significance are presented according to the values of: *,**,*** indicating the level of significance at $10 \%$ to $5 \%$ and $1 \%$ respectively.

Table 12 shows the regression results of model 3 and 4 . This table represents the relationship between ISO 14001 and ISO 26001, with the financial profitability of the company. The results show empirical support for $\mathrm{H} 3 \mathrm{a}, \mathrm{H} 3 \mathrm{~b}, \mathrm{H} 3 \mathrm{c}, \mathrm{H} 3 \mathrm{~d}, \mathrm{H} 4 \mathrm{a}$ and $\mathrm{H} 4 \mathrm{~d}$. However, for $\mathrm{H} 4 \mathrm{~b}$, and $\mathrm{H} 4 \mathrm{c}$, we do not find empirical support. The hypotheses H3a, presents significant and negative effects according to the value of $(\beta=-0.170, p<0.001)$, Indicating that less importance in the implementation of environmental standards, the company achieves less market share. The hypotheses $\mathrm{H} 3 \mathrm{~b}, \mathrm{H} 3 \mathrm{c}$ and $\mathrm{H} 3 \mathrm{~d}$ present a strong and significant positive influence on the financial profitability according to the values of $(\beta=0.200, p<0.001),(\beta=0.142, p<0.001)$ y $(\beta=0.182, p<0.001)$. This allows us to assume that the implementation and execution of ISO 14001 in the SME increases the financial profitability. H4a and H4d indicate that ISO 26001 has a positive and significant influence on market share and overall profitability, according to the values of $(\beta=0.128, p<0.05)$ y $(\beta=0.121, p<0.05)$. In relation to the control variables introduced in the statistical models, we have detected that only the size of the company has a positive and significant influence on the variable market share according to the value of $(\beta=0.126, p<0.001)$. To validate the linear regression models of the hypothesis, the $\mathrm{R}^{2}$ adjusted with a value of $(0.047),(0.070),(0.037)(0.062)$ and values of $\mathrm{F}\left(3.657^{* * *}\right),\left(5.151^{* * *}\right),\left(2.594^{* * *}\right)$ y $\left(5.485^{* * *}\right)$. In addition, the independent variables of the linear regression model show thevariance inflation factor (VIF) close to the unit of (1.29), (1.28), (1.29) and (1.28), ruling out the presence of multicollinearity.

\section{Conclusion and Discussion}

The results of the research are derived from the analysis of a sample of 215 SMEs from the services, trade and industrial sectors. The study has been developed in a context plagued by strict environmental regulations, commercial uncertainty and complicated international financial markets (Gunningham, Sinclair, \& Sinclair, 2017; Revell, Stokes, \& Chen, 2009; Tasdemir, Gazo, Tasdemir, \& Gazo, 2018). The results confirm that SMEs established in the southern region of the State of Sonora in Mexico have placed greater interest in compliance with environmental regulations imposed by government institutions and have been minimizing CSR actions. The main contribution of the study is to corroborate that the SMEs established in this region, which are part of the business fabric of a country submerged in the development and economic growth, are in an initial phase and on 
the right path towards the implementation of environmental practices and of social responsibility. In this section, we discuss our results in the context of the literature on the influence exerted by the ISO standards of environmental management and social responsibility, on the image and business profitability that is manifested in the SME. This research first shows that the SMEs that guide their resources and capabilities in environmental actions significantly improve their image, particularly in: 1) the perception of an innovative company, 2) a leading company in the market, 3 ) and as a safe company. In addition, these sustainable strategies contribute to: 1) increase in customer satisfaction and 2) increase in business profits. Secondly, we corroborate that SMEs that practice social responsibility actions achieve significant results in: 1) being viewed as a safe company, 2) in increasing market share and 3) in the overall profitability of the SME. With the above we have given answers to the questions and the objective of the investigation. Analyzing our results in greater depth, we show relevant empirical evidence on the influence of ISO 14001 on the image and profitability of SMEs. First, the result with greater strength is located in the regression model 1, demonstrating that environmental management standards have a positive and significant impact on the image of SMEs. These results are aligned with the literature related to environmental management (Stakeholders) and with the theory of resources and organizational capabilities (Hahn \& Kühnen, 2013; McWilliams \& Siegel, 2001). In this same direction with an important force the regression model 3, states that environmental management significantly influences the profitability of SMEs, results that align with the Stakeholder literature and sustainability and, in addition, with some empirical studies (Cantele \& Zardini, 2018; Ferrón-Vílchez, 2016; Freeman et al., 2010). Regarding model 2, we observe that there is a smaller influence between ISO 26001 and the business image. These findings have a similar behavior with model 4, which indicates that there is a significant but smaller relationship between ISO 26001 and the profitability obtained in the SME. This allows us to argue that these types of businesses are not adopting these strategies in their entirety, this is mainly due to their limitations and barriers they face in global markets and economies of scale, as enunciated by different theoretical and empirical studies (Hahn, 2012; Lee, Herold, \& Yu, 2016; Lepoutre \& Heene, 2006). From the above, it can be deduced that SMEs must focus their resources and capacities on sustainable business and models, on the adoption of ISO standards for environmental management and even more on implementing CSR practices through ISO 26001. These strategic actions can lead to competitiveness in global terrains and to sustained profitability for all interest groups that participate directly or indirectly in the business. On the other hand, it has been detected that the variable size of the company has a positive and significant impact in a partial way, in the image variable particularly in: (innovative company) and in the variable profitability specifically in: the (increase in market share). In other words, the companies that focus their resources (human, technological and financial capital), and their capabilities (broad knowledge of the market, increase the quality of products through innovation and standardize their production processes), can be achieved improve the satisfaction of customers and other interest groups (Aras, Aybars, \& Kutlu, 2010; Davis, Babakus, Englis, \& Pett, 2010). But these results also indicate that the larger the company, the more complex and difficult to control, so organizations can become insecure from the point of view of the organizational structure (complexity of resource management) (Teece, 2007; Teece, Pisano, \& Shuen, 1997). Results that are aligned with the theory of resources and capabilities and with evolutionary economic theory (Barney et al., 2011; Nelson, 2009).

The research exhibits some limitations and on the other hand it opens the door to continue developing future lines of research. The first limitation refers to the fact that the information can stimulate the bias of the results, this because the data were obtained from subjective perceptions issued by the managers and/or managers of the SME. Second, the sample has only been focused on companies in the southern zone of the State of Sonora in Mexico, and may be extended to other geographical areas of the country. The last limitation considered in this paper is about the type of statistical analysis carried out for the verification of hypotheses (linear regression). In addition to continue with this type of studies, an important issue to develop further analysis, is to verify the alignment and synchronized execution between ISO 140001 and ISO26001, in order to find the effect of these variables on profitability for companies through of longitudinal type studies. In order to face these limitations, it is important to consider, in the future, the consolidation of the conceptual model on the subject of sustainability, social responsibility, image and profitability through the inclusion of a greater number of constructs. With this, we intend to strengthen the analyzes through the use of the structural equations technique (variance and/or covariance). To continue in this same direction and develop high value studies, it is advisable to continue with this type of studies considering variables such as: 1) innovation 2) sustainable entrepreneurship and 3) the supply chain in SMEs. 


\section{Acknowledgments}

This research has been developed by the research group in Management and Business Development of the Technological Institute of Sonora of Mexico, in collaboration with the University of Extremadura Spain. The research has been supported financially by the Ministry of Public Education of Mexico through the Program for Strengthening Educational Quality (PFCE, 2018).

\section{References}

Aagaard, A. (2016). Sustainable Business: River Publishers. Retrieved from https://books.google.com.mx/books?id=ExvkDAAAQBAJ

Ageron, B., \& Spalanzani, A. (2012). Sustainable supply management: An empirical study. International Journal of Production Economics, 140(1), 168-182. https://doi.org/10.1016/J.IJPE.2011.04.007

Aras, G., Aybars, A., \& Kutlu, O. (2010). Managing corporate performance. International Journal of Productivity and Performance Management, 59(3), 229-254. https://doi.org/10.1108/17410401011023573

Bansal, P., \& Hunter, T. (2003). Strategic Explanations for the Early Adoption of ISO 14001. Journal of Business Ethics, 46(3), 289-299. https://doi.org/10.1023/A:1025536731830

Barney, J. B. (2012). Purchasing, Supply Chain Management and Sustained Competitive Advantage: The Relevance of Resource-based Theory. Journal of Supply Chain Management, 48(2), 3-6. https://doi.org/10.1111/j.1745-493X.2012.03265.x

Barney, J. B., Ketchen, D. J., \& Wright, M. (2011). The future of resource-based theory: Revitalization or decline? Journal of Management, 37(5), 1299-1315. https://doi.org/10.1177/0149206310391805

Barney, J., Wright, M., \& Ketchen, D. J. (2001). The resource-based view of the firm: Ten years after 1991. Journal of Management, 27(6), 625-641. https://doi.org/10.1016/S0149-2063(01)00114-3

Benitez-Amado, J., \& Walczuch, R. M. (2012). Information technology, the organizational capability of proactive corporate environmental strategy and firm performance: a resource-based analysis. European Journal of Information Systems, 21(6), 664-679. https://doi.org/10.1057/ejis.2012.14

Bernal-Conesa, J. A., de Nieves Nieto, C., \& Briones-Peñalver, A. J. (2017). CSR Strategy in Technology Companies: Its Influence on Performance, Competitiveness and Sustainability. Corporate Social Responsibility and Environmental Management, 24(2), 96-107. https://doi.org/10.1002/csr.1393

Camilleri, M. A. (2017). Corporate Sustainability, Social Responsibility and Environmental Management: An Introduction to Theory and Practice with Case Studies. Springer International Publishing. Retrieved from https://books.google.com.mx/books?id=iZ47DgAAQBAJ

Cantele, S., \& Zardini, A. (2018). Is sustainability a competitive advantage for small businesses? An empirical analysis of possible mediators in the sustainability-financial performance relationship. Journal of Cleaner Production, 182, 166-176. https://doi.org/10.1016/j.jclepro.2018.02.016

Carroll, A. B., \& Shabana, K. M. (2010). The Business Case for Corporate Social Responsibility: A Review of Concepts, Research and Practice. International Journal of Management Reviews, 12(1), 85-105. https://doi.org/10.1111/j.1468-2370.2009.00275.x

Chin, W. W., \& Dibbern, J. (2010). Handbook of Partial Least Squares. Springer Berlin Heidelberg. https://doi.org/10.1007/978-3-540-32827-8

Christmann, P. (2004). Multinational Companies and the Natural Environment: Determinants of Global Environmental Policy Standardization. Academy of Management, 47(5), 747-760. Retrieved from http://www.jstor.org/stable/20159616

Cohen, P., West, S. G., \& Aiken, L. S. (2014). Applied Multiple Regression/Correlation Analysis for the Behavioral Sciences (2nd ed.). New York, NY. Retrieved from https://www.taylorfrancis.com/books/9781135468255

Davis, P. S., Babakus, E., Englis, P. D., \& Pett, T. (2010). The influence of CEO gender on market orientation and performance in service small and medium-sized service businesses. Journal of Small Business Management, 48(4), 475-496.

Dey, P. K., Petridis, N. E., Petridis, K., Malesios, C., Nixon, J. D., \& Ghosh, S. K. (2018). Environmental management and corporate social responsibility practices of small and medium-sized enterprises. Journal of Cleaner Production, 195, 687-702. https://doi.org/10.1016/J.JCLEPRO.2018.05.201 
Dobers, P. (2009). Corporate social responsibility: management and methods. Corporate Social Responsibility and Environmental Management, 16(4), 185-191. Retrieved from http://onlinelibrary.wiley.com/doi/10.1002/csr.201/full

Drucker, P. (2012). Managing in the Next Society. Taylor \& Francis. Retrieved from https://books.google.com.mx/books?id=wAFdkE3GFpoC

Ferrón-Vílchez, V. (2016). Does symbolism benefit environmental and business performance in the adoption of ISO 14001? Journal of Environmental Management, 183, 882-894. https://doi.org/10.1016/J.JENVMAN.2016.09.047

Finkbeiner, M., Schau, E. M., Lehmann, A., Traverso, M., Finkbeiner, M., Schau, E. M., ... Traverso, M. (2010). Towards Life Cycle Sustainability Assessment. Sustainability, 2(10), 3309-3322. https://doi.org/10.3390/su2103309

Freeman, R. E. (2010). Strategic Management: A Stakeholder Approach. Cambridge University Press. Retrieved from https://books.google.com.mx/books?id=NpmA_qEiOpkC

Freeman, R. E., Harrison, J. S., Wicks, A. C., Parmar, B. L., \& de Colle, S. (2010). Stakeholder Theory: The State of the Art. Cambridge University Press. Retrieved from https://books.google.com.mx/books?id=xF8-WN1Q1IMC

Gefen, D., Straub, D., \& Boudreau, M. C. (2000). Structural Equation Modeling and Regression: Guidelines for Research Practice. Communications of the Association for Information Systems, 4. https://doi.org/10.17705/1CAIS.00407

Gianni, M., Gotzamani, K., \& Tsiotras, G. (2017). Multiple perspectives on integrated management systems and corporate sustainability performance. Journal of Cleaner Production, 168, 1297-1311. https://doi.org/10.1016/J.JCLEPRO.2017.09.061

Graafland, J. (2018). Does Corporate Social Responsibility Put Reputation at Risk by Inviting Activist Targeting? An Empirical Test among European SMEs. Corporate Social Responsibility and Environmental Management, 25(1), 1-13. https://doi.org/10.1002/csr.1422

Granly, B. M., \& Welo, T. (2014). EMS and sustainability: experiences with ISO 14001 and Eco-Lighthouse in Norwegian metal processing SMEs. Journal of Cleaner Production, 64, 194-204. https://doi.org/10.1016/J.JCLEPRO.2013.08.007

Gunningham, N., Sinclair, D., \& Sinclair, D. (2017). Leaders and Laggards. Routledge. https://doi.org/10.4324/9781351282000

Hahn, R. (2012). Standardizing social responsibility new perspectives on guidance documents and management system standards for sustainable development. IEEE Transactions on Engineering Management, 59(4), 717-727. https://doi.org/10.1109/TEM.2012.2183639

Hahn, R., \& Kühnen, M. (2013). Determinants of sustainability reporting: A review of results, trends, theory, and opportunities in an expanding field of research. Journal of Cleaner Production, 59(November), 5-21. https://doi.org/10.1016/j.jclepro.2013.07.005

Heras, I., \& Arana, G. (2010). Alternative models for environmental management in SMEs: the case of Ekoscan vs. ISO 14001. Journal of Cleaner Production, 18(8), 726-735. https://doi.org/10.1016/J.JCLEPRO.2010.01.005

Hillary, R. (2004). Environmental management systems and the smaller enterprise. Journal of Cleaner Production, 12(6), 561-569. https://doi.org/10.1016/J.JCLEPRO.2003.08.006

Ho, K. L. P., Nguyen, C. N., Adhikari, R., Miles, M. P., \& Bonney, L. (2017). Exploring market orientation, innovation, and financial performance in agricultural value chains in emerging economies. Journal of Innovation \& Knowledge, 3(3), 154-163. https://doi.org/10.1016/j.jik.2017.03.008

Israel, G. D. (1992). Determining Sample Size 1 The Level of Precision.

Jagd, J. T. (2014). Investor Oriented Corporate Social Responsibility Reporting. Taylor \& Francis. Retrieved from https://books.google.com.mx/books?id=FKZeBAAAQBAJ

Jamali, D., \& Karam, C. (2018). Corporate Social Responsibility in Developing Countries as an Emerging Field of Study. International Journal of Management Reviews, 20(1), 32-61. https://doi.org/10.1111/ijmr.12112 
Jayanti, R. K., \& Rajeev Gowda, M. V. (2014). Sustainability dilemmas in emerging economies. IIMB Management Review, 26(2), 130-142. https://doi.org/10.1016/j.iimb.2014.03.004

Jenkins, H. (2004). A Critique of Conventional CSR Theory: An SME Perspective. Journal of General Management, 29(4), 37-57. https://doi.org/10.1177/030630700402900403

Khan, M. I., \& Chang, Y. C. (2018). Environmental Challenges and Current Practices in China-A Thorough Analysis. Sustainability, 10(7), 2547. https://doi.org/10.3390/su10072547

Kleinbaum, D., Kupper, L., Nizam, A., \& Rosenberg, E. (2013). Applied Regression Analysis and Other Multivariable Methods (3rd ed.). Nesol Education.

Lee, K. H., Herold, D. M., \& Yu, A. L. (2016). Small and Medium Enterprises and Corporate Social Responsibility Practice: A Swedish Perspective. Corporate Social Responsibility and Environmental Management, 23(2), 88-99. https://doi.org/10.1002/csr.1366

Lee, M. D. P. (2008). A review of the theories of corporate social responsibility: Its evolutionary path and the road ahead. International Journal of Management Reviews, 10(1), 53-73. https://doi.org/10.1111/j.1468-2370.2007.00226.x

Lepoutre, J., \& Heene, A. (2006). Investigating the Impact of Firm Size on Small Business Social Responsibility: A Critical Review. Journal of Business Ethics, 67(3), 257-273. https://doi.org/10.1007/s10551-006-9183-5

Lueg, R., \& Radlach, R. (2016). Managing sustainable development with management control systems: A literature review. European Management Journal, 34(2), 158-171. https://doi.org/10.1016/J.EMJ.2015.11.005

Masurel, E. (2007). Why SMEs invest in environmental measures: sustainability evidence from small and medium-sized printing firms. Business Strategy and the Environment, 16(3), 190-201. https://doi.org/10.1002/bse.478

McCormick, K., \& Kautto, N. (2013). The Bioeconomy in Europe: An Overview. Sustainability, 5(6), 25892608. https://doi.org/10.3390/su5062589

McWilliams, A., Parhankangas, A., Coupet, J., Welch, E., \& Barnum, D. T. (2016). Strategic Decision Making for the Triple Bottom Line. Business Strategy and the Environment, 25(3), 193-204. https://doi.org/10.1002/bse.1867

McWilliams, A., \& Siegel, D. (2001). Corporate Social Responsibility: A Theory of The Firm Perspective. Academy of Management Review, 26(1), 117-127. https://doi.org/10.5465/AMR.2001.4011987

McWilliams, A., Siegel, D. S., \& Wright, P. M. (2006). Corporate social responsibility: Strategic implications. Journal of Management Studies, 43(1), 1-18. https://doi.org/10.1111/j.1467-6486.2006.00580.x

Melnyk, S. A., \& Tobias, J. (2014). Is performance measurement and management fit for the future? Management Accounting Research, 25(2), 173-186. https://doi.org/10.1016/J.MAR.2013.07.007

Moore, S. B., \& Manring, S. L. (2009). Strategy development in small and medium sized enterprises for sustainability and increased value creation. Journal of Cleaner Production, 17(2), 276-282. https://doi.org/10.1016/J.JCLEPRO.2008.06.004

Moratis, L., \& Cochius, T. (2017). ISO 26000: The Business Guide to the New Standard on Social Responsibility. Taylor \& Francis group. Retrieved from https://books.google.com.mx/books?id=2qk0DwAAQBAJ

Naing, L., Winn, T., \& Rusli, B. N. (2006). Practical Issues in Calculating the Sample Size for Prevalence Studies. Archives of Orofacial Sciences, 1. Retrieved from http://www.dental.usm.my/aos/docs/Vol_1/09_14_ayub.pdf

Neil A. M., Anna K., \& Katsikeas, C. S. (2004). Antecedents of Export Venture Performance: A Theoretical Model and Empirical Assessment. Journal of Marketing, 68(1), 90-108. https://doi.org/10.1509/jmkg.68.1.90.24028

Nelson, R. R. (2009). An Evolutionary Theory of Economic Change. Harvard University Press. Retrieved from https://books.google.com.mx/books?id=6Kx7s_HXxrkC

Nwachukv, S., Vitell, S., Gilbert, F., \& Barnes, J. (1997). Ethics and social responsibility in marketing: An examination of the ethics evaluation of advertising strategies. Journal of Business Research, 39(2), 107-188. Retrieved from http://www.sciencedirect.com/science/article/pii/S0148296396001464 
Orlitzky, M., Schmidt, F. L., \& Rynes, S. L. (2003). Corporate Social and Financial Performance: A Meta-Analysis. Organization Studies, 24(3), 403-441. https://doi.org/10.1177/0170840603024003910

Penrose, E. T. (2009). The Theory of the Growth of the Firm. Oxford University Press. Retrieved from https://books.google.com.mx/books?id=zCAUDAAAQBAJ

Porter, M. E., \& Kramer, M. R. (2011). Creating shared value. Harvard Business Review, February, 63-77. https://doi.org/10.1108/09600039410055963

Poveda, C. A., \& Young, R. (2015). Potential benefits of developing and implementing environmental and sustainability rating systems: Making the case for the need of diversification. International Journal of Sustainable Built Environment, 4(1), 1-11. https://doi.org/10.1016/J.JJSBE.2014.12.003

Rajeev, A., Pati, R. K., Padhi, S. S., \& Govindan, K. (2017). Evolution of sustainability in supply chain management: A literature review. Journal of Cleaner Production, 162, 299-314. https://doi.org/10.1016/J.JCLEPRO.2017.05.026

Rego, A., Cunha, M. P. E, \& Polónia, D. (2017). Corporate Sustainability: A View from the Top. Journal of Business Ethics, 143(1), 133-157. https://doi.org/10.1007/s10551-015-2760-8

Revell, A., Stokes, D., \& Chen, H. (2009). Small businesses and the environment: turning over a new leaf? Business Strategy and the Environment, 19(5), 273-288. https://doi.org/10.1002/bse.628

Salim, H. K., Padfield, R., Hansen, S. B., Mohamad, S. E., Yuzir, A., Syayuti, K., ... Papargyropoulou, E. (2018). Global trends in environmental management system and ISO14001 research. Journal of Cleaner Production, 170, 645-653. https://doi.org/10.1016/J.JCLEPRO.2017.09.017

Sarantakos, S. (2001). The importance of pilot studies. Social Research, 1(35), 9. https://doi.org/10.1007/978-1-349-13387-1

Sarbutts, N. (2003). Can SMEs "do" CSR? A practitioner's view of the ways small- and medium-sized enterprises are able to manage reputation through corporate social responsibility. Journal of Communication Management, 7(4), 340-347. https://doi.org/10.1108/13632540310807476

Sharma, S., \& Vredenburg, H. (1998). Proactive corporate environmental strategy and the development of competitively valuable organizational capabilities. Strategic Management Journal, 19(8), 729-753. https://doi.org/10.1002/(SICI)1097-0266

Spence, L. J. (2016). Small Business Social Responsibility. Business \& Society, 55(1), $23-55$. https://doi.org/10.1177/0007650314523256

Su, H.-C., Dhanorkar, S., \& Linderman, K. (2015). A competitive advantage from the implementation timing of ISO management standards. Journal of Operations Management, 37, 31-44. https://doi.org/10.1016/J.JOM.2015.03.004

Tasdemir, C., Gazo, R., Tasdemir, C., \& Gazo, R. (2018). A Systematic Literature Review for Better Understanding of Lean Driven Sustainability. Sustainability, 10(7), 25-44. https://doi.org/10.3390/su10072544

Teece, D. J. (2007). Explicating Dynamic Capabilities: The Nature and Microfoundations of (Sustainabile) Enterprise Performance. Strategic Management Journal, 298(13), 1319-1350.

Teece, D. J., Pisano, G., \& Shuen, A. (1997). Dynamic capabilities and strategic management. Strategic Management Journal, 18(7), 509-533. https://doi.org/10.1002/(SICI)1097-0266

Torugsa, N. A., O’Donohue, W., \& Hecker, R. (2012). Capabilities, Proactive CSR and Financial Performance in SMEs: Empirical Evidence from an Australian Manufacturing Industry Sector. Journal of Business Ethics, 109(4), 483-500. https://doi.org/10.1007/s10551-011-1141-1

Valdez-Juárez, L., Gallardo-Vázquez, D., Ramos-Escobar, E., Valdez-Juárez, L. E., Gallardo-Vázquez, D., \& Ramos-Escobar, E. A. (2018). CSR and the Supply Chain: Effects on the Results of SMEs. Sustainability, 10(7), 2356. https://doi.org/10.3390/su10072356

von Weltzien Hoivik, H. (2011). Embedding CSR as a learning and knowledge creating process: the case for SMEs in Norway. Journal of Management Development, 30(10), 1067-1084. https://doi.org/10.1108/02621711111182547

Wilcox, R. R. (1997). Some practical reasons for reconsidering the Kolmogorov-Smirnov test. British Journal of Mathematical and Statistical Psychology, 50(1), 9-20. https://doi.org/10.1111/j.2044-8317.1997.tb01098.x 
Wilcox, R. R., \& Spring. (2007). ANOVA: A Paradigm for Low Power and Misleading Measures of Effect Size? ANOVA: A Paradigm for Low Power and Misleading Measures of Effect Size? Review Literature and Arts of the Americas, 65(1), 51-77.

Witjes, S., \& Lozano, R. (2016). Towards a more Circular Economy: Proposing a framework linking sustainable public procurement and sustainable business models. Resources, Conservation and Recycling, 112, 37-44. https://doi.org/10.1016/J.RESCONREC.2016.04.015

Wood, D. J. (2010). Measuring Corporate Social Performance: A Review. International Journal of Management Reviews, 12(1), 50-84. https://doi.org/10.1111/j.1468-2370.2009.00274.x

\section{Appendix A}

\section{Survey for the Application of ISO 14001 and ISO 26001 in Mipymes}

Dear company director, we are conducting research to determine the level and/or degree of application of the rules on Social Responsibility and Environmental Management in MSMEs in the south of the State of Sonora. We look forward to your cooperation by answering the following questions. The information you provide will be treated with absolute confidentiality and will be used only for academic purposes.

\section{BLOCK I: GENERAL DATA OF THE COMPANY}

Company name:

City: Zip Code:

Activity sector:

1. How many years has your company been operating?

2. How many employees does your company have?

3. The gender of the director/or manager of the company is:

$$
\text { Male Female }
$$

4. What is the age of the manager?.

5. What is the level of academic preparation of the director/or manager of the company?

\begin{tabular}{ll}
\hline Basic education & High school \\
Technical career & Bachelor or Engineering \\
master's degree & Doctoral Studies $(\mathrm{PhD})$ \\
\hline
\end{tabular}

6. Indicate if, your company has implemented the ISO14001 standard in its internal processes in the last two years?

$$
\text { Yes No }
$$

7. Indicate if, your company has implemented ISO 26001 in its internal processes in the last two years?

$$
\text { Yes No }
$$

\section{BLOCK II: BUSINESS IMAGE}

\begin{tabular}{|c|c|c|c|c|c|c|}
\hline BI1 & It is an innovative company & 1 & 2 & 3 & 4 & 5 \\
\hline BI2 & It is a leading company in its sector & 1 & 2 & 3 & 4 & 5 \\
\hline $\mathrm{BI} 3$ & It is a company that offers security to its stakeholders & 1 & 2 & 3 & 4 & 5 \\
\hline
\end{tabular}

8. Indicate the evolution of the following aspects in your company in the last two years.

\section{BLOCK III: FINANCIAL PERFORMANCE}

9. Indicate the evolution of the following aspects in your company in the last two years.

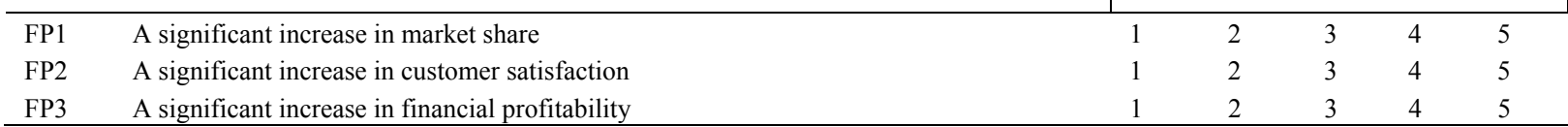




\section{Copyrights}

Copyright for this article is retained by the author(s), with first publication rights granted to the journal.

This is an open-access article distributed under the terms and conditions of the Creative Commons Attribution license (http://creativecommons.org/licenses/by/4.0/). 